\author{
Jan Kulesza \\ Uniwersytet Łódzki \\ ORCID: 0000-0002-0574-9120 \\ jkulesza@wpia.uni.lodz.pl
}

\title{
Glosa do wyroku Sądu Okręgowego w Opolu z dnia 10 grudnia 2018 r. (VII Ka 956/18, niepubl.)
}

\author{
Gloss to the Judgement of the District Court in Opole of \\ 10 December 2018 (VII Ka 956/18, Unpublished)
}

\section{STRESZCZENIE}

W glosowanym wyroku sąd uwolnił od odpowiedzialności za wykroczenie umieszczenia w miejscu publicznym nieprzyzwoitego rysunku (art. 141 k.w.) osoby, które przed szpitalem położniczym w Opolu prezentowały banery ze zdjęciami szczątków ludzkich po wykonanym zabiegu aborcji. Nie tylko uwolnienie od odpowiedzialności za to wykroczenie było błędne, choć możliwe jest w takich wypadkach stosowanie również art. 140 k.w. (odpowiedzialność za publiczny nieobyczajny wybryk). Sąd zastosował także całkowicie błędną wykładnię znamienia nieprzyzwoitości i obyczajności publicznej jako ograniczających się do sfery intymnej i płciowej. Wykładnie historyczna, prawnoporównawcza, językowa, celowościowa i systemowa wskazują, że obyczajność publiczna obejmuje powszechnie przyjęty i wymagany sposób publicznego zachowania, którego naruszenie wywołuje lub może wywołać negatywną reakcję innych osób w postaci zażenowania, zgorszenia, gniewu, sprzeciwu, potępienia. Nieobyczajne zachowanie to takie, które sprzeciwia się normom kulturowym, zasadom współżycia społecznego, przyjętym zwyczajom publicznych zachowań jednostek.

Słowa kluczowe: działalność pro-life; wolność wypowiedzi; moralność publiczna; porządek publiczny; odpowiedzialność karna

1. Słownikowa definicja pojęcia ,nieprzyzwoity” sprowadza się do równoznacznych wyrazów, jak nieskromny, bezwstydny, nieobyczajny - odnoszących się do norm związanych z intymnością. Dlatego można z całą pewnością uznać, że znaczenie słowa ,nieprzyzwoity” w ogólnym języku polskim jest zawężone do 
przekroczenia norm związanych z obyczajnością jako zespołu norm oddzielających w społeczeństwie to, co intymne od tego, co publiczne.

2. Skoro obyczajność w k.k. oznacza normy dotyczące zachowań z zakresu seksualności człowieka, to posłużenie się tym terminem w k.w., przy założeniu racjonalności ustawodawcy, musi mieć takie samo znaczenie.

3. Wykładnia systemowa powinna też wziąć pod uwagę kontekst Rozdziału XXV k.k. 1997 r. zatytułowanego „Przestępstwa przeciwko wolności seksualnej i obyczajności” oraz Rozdziału XVI k.w. zatytułowanego „Wykroczenia przeciwko obyczajności publicznej”. Słowo „obyczajność” odnosi się więc do wąskiej sfery norm dotyczących spraw intymnych. Przymiotnik ,publiczna” wzmacnia to znaczenie, świadcząc jednoznacznie o tym, że dobrem chronionym jest utrzymanie intymnej sfery życia w miejscach publicznych w odpowiednich, powszechnie przyjętych ryzach.

4. Trzy poszczególne typy wykroczeń z Rozdziału XVI k.w., opisane w art. 140142 k.w., mieszczą się w tak przyjętym polu semantycznym. W tych ramach byłoby zupełnie nieracjonalne, aby art. 141 k.w. odrywał się od pola semantycznego rozdziału i odsyłał do wszelkich norm moralnych bądź estetycznych w ogólności. [...] Wykładnia systemowa nakazuje więc ograniczyć zakres znaczonych zjawisk do tych związanych z intymnością fizjologii i płciowości. Gdyby było inaczej, przepis art. 141 nie zostałby umieszczony pośrodku przepisów penalizujących zachowania obsceniczne i godzące w moralność seksualną.

\section{$* * *$}

W glosowanym wyroku sąd uwolnił od odpowiedzialności za wykroczenie kilka osób skazanych przez sąd pierwszej instancji za umieszczenie w miejscu publicznym nieprzyzwoitego rysunku (art. 141 k.w.). Osoby te podczas dwóch legalnych zgromadzeń przy Centrum Ginekologii, Położnictwa i Neonatologii w Opolu prezentowały banery ze zdjęciami szczątków ludzkich po wykonanym zabiegu aborcji. Zarówno z odrzuceniem odpowiedzialności z art. 141 k.w. ${ }^{1}$, jak i z tezami sformułowanymi przez sąd zgodzić się nie można². Sąd powołuje się na przeprowadzoną przez siebie

$1 \mathrm{Na}$ temat podstaw odpowiedzialności z tego przepisu innych jeszcze niż omówione w tej glosie zob. J. Kulesza, Glosa do wyroku Sadu Okregowego we Wrocławiu z 25.07.2019 r., IV Ka 677/19, „Państwo i Prawo” (złożona do druku).

2 Na temat innych możliwych kwalifikacji tego rodzaju zachowań z art. $51 \S 1$ i art. 140 k.w. zob. idem, Publiczne prezentowanie zdjęć martwych płodów jako nieobyczajny wybryk (art. 140 Kodeksu wykroczeń), „Studia Prawnicze” 2019, nr 2; idem, Publiczne prezentowanie zdjęć martwych płodów jako wybryk zakłócenia spokoju i porządku publicznego bądź wywołania zgorszenia (art. 51 \& 1 Kodeksu wykroczeń), „Ruch Prawniczy, Ekonomiczny i Socjologiczny” (złożony do druku); idem, Publiczne prezentowanie zdjęć martwych płodów przez działaczy pro-life w orzecznictwie sądów powszechnych. 
(i, niestety, tylko przez siebie, bez sięgnięcia do choćby jednej pozycji z zakresu literatury przedmiotu) wykładnię, przy czym ulega jedynie iluzji co do efektu swych dokonań oraz ich logicznej i merytorycznej poprawności.

Przede wszystkim jako zdumiewający należy potraktować tok rozumowania sądu, który wychodząc od słownikowego znaczenia zaledwie jednego znamienia nieprzyzwoitości, wnioskuje nie tylko o przedmiocie ochrony art. 141 k.w., lecz także całego Rozdziału XVI k.w. Poprawnie przeprowadzona wykładnia nakazywałaby najpierw określenie rodzajowego przedmiotu ochrony wspólnego dla wszystkich wykroczeń zgromadzonych w tym rozdziale, poczynając od wykładni historycznej i związanej z nią wykładni celowościowej, przez wykładnię językową pojęcia „obyczajność publiczna”, aż po logicznie poprawnie przeprowadzoną wykładnię systemową. Dopiero wówczas można by było ewentualnie przejść do zdefiniowania pojęcia „nieprzyzwoitość” na gruncie art. 141 k.w., rozważając, czy jest ono tak szerokie, jak wynika z dokonanej już wykładni, czy może jest węższe, lecz na gruncie właśnie tego jednego wykroczenia, w którym się pojawia.

Art. 141 k.w. został w obowiązującym Kodeksie wykroczeń wyodrębniony z zakresu karalności art. 140 k.w. ${ }^{3}$ Co istotne, już pierwotną treść art. 31 Prawa o wykroczeniach z 1932 r. (poprzednik art. 140 k.w.) uzupełniono nowelizacją z dnia 9 kwietnia 1946 r. ${ }^{4} \mathrm{w}$ ten sposób, że przepis ten przyjął brzmienie: „Kto publicznie dopuszcza się nieobyczajnego wybryku lub używa słów nieprzyzwoitych, podlega karze [...]". Pierwotne źródło art. 140 i 141 k.w. jest zatem takie samo i stanowi je art. 31 Prawa o wykroczeniach z 1932 r. Ten przepis z kolei bierze swój początek ${ }^{5}$ m.in. w Części XIII „O pogwałceniu przepisów o nadzorze nad moralnością publiczną" Kodeksu karnego rosyjskiego (dalej jako: k.k.r.) z 1903 r. Art. 280 owego Kodeksu stanowił: „Winny publicznego pogwałcenia przystojności przez wypowiedzenie słów bezwstydnych lub przez postępek bezwstydny będzie karany. [...] Jeżeli postępek bezwstydny polegał na lubieżnym lub innym przeciw-

Analiza krytyczna, [w:] Pro dignitate legis et maiestate iustitiae. Księga jubileuszowa z okazji 70. rocznicy urodzin Profesora Witolda Kuleszy, red. A. Liszewska, J. Kulesza, Łódź 2020. Odnośnie do braku naruszenia prawa do wolności wypowiedzi w przypadku skazania z art. 140, 141 albo 51 k.w. zob. idem, Wybryk nieobyczajny publicznego prezentowania zdjęć martwych płodów a ochrona wolności wypowiedzi w świetle orzecznictwa ETPC, „Studia Prawno-Ekonomiczne” (przyjęty do druku).

A. Gubiński, Prawo wykroczeń, Warszawa 1985, s. 336; idem, [w:] T. Grzegorczyk, A. Gubiński, Prawo wykroczeń, Warszawa 1996, s. 253.

4 Dekret z dnia 9 kwietnia 1946 r. o zmianie prawa o wykroczeniach (Dz.U. 1946, nr 15, poz. 108).

Czerpano inspirację również z prawa austriackiego, niemieckiego, szwajcarskiego i czechosłowackiego. Por. Projekt wstępny Ustawy o wykroczeniach, oprac. E.S. Rappaport, t. 4, z. 4, Komisja Kodyfikacyjna Rzeczypospolitej Polskiej. Sekcja Prawa Karnego, Warszawa 1929; Projekt wstepny Ustawy o wykroczeniach administracyjnych wraz z sumarycznem uzasadnieniem, oprac. E.S. Rappaport, R. Lemkin, t. 5, z. 7, Komisja Kodyfikacyjna Rzeczypospolitej Polskiej. Sekcja Prawa Karnego, Warszawa 1931. 
nym moralności czynie, połączonym ze zgorszeniem innych osób, to winowajca, jeśli nie ulega karze surowszej za nierząd, będzie karany [...]".

Przedmiot ochrony tego typu rodzajowego zwięźle określili A. Mogilnicki i E.S. Rappaport, stwierdzając, że jest nim „moralność publiczna, dotknięta publiczną obrazą poczucia przystojności i wstydu" , podążając za orzeczeniami Sądu Najwyższego z dnia 30 stycznia 1922 r. ${ }^{7}$ oraz z dnia 11 czerwca 1923 r. ${ }^{8}$ Odnośnie do określenia tego, co publicznie przystoi czynić, W. Makowski wskazywał:

[...] pojęcie przystojności lub nieprzystojności wyrazu lub gestu jest $\mathrm{z}$ istoty rzeczy bardzo względne i rozciągłe i nie można w sposób kategoryczny podać z góry określenia tego rodzaju wyrazów i gestów. Przeciętna moralność społeczna, o ile można ją ustalić mocą przekonania sędziowskiego, stanowić powinna taki probierz, z uwzględnieniem, oczywiście, okoliczności indywidualnych wypadku, środowiska, widowni, charakteru i celu działania. Obnażenie ciała lub niektórych jego części może mieć cechy czynu bezwstydnego zależnie od warunków i celu, w jakim je uczyniono, ale to samo obnażenie modela w szkole sztuk pięknych dla celów artystycznych nie będzie czynem nieprzystojnym itp. Istotną cechą jest zgorszenie publiczne, które w ten sposób nie tylko mogłoby być wywołane, w innych warunkach, ale rzeczywiście jest właściwe działaniu w tych warunkach, w jakich się ono odbywa9 9

\section{Zdaniem N. Tagancewa przepis ten odnosił się do:}

[...] wszystkich czynów niemoralnych, które gwałcą zasady przystojności publicznej za pomocą takiego postępowania publicznego, które obraża pojęcia moralności ogólnej i obejmuje on również postępowanie lubieżne oraz inne sposoby zaspakajania namiętności płciowych, jak np. sodomję, onanizm itp., jeżeli tylko czynów dokonano w okolicznościach wywołujących zgorszenie innych osób ${ }^{10}$.

Owe „słowa bezwstydne”, które pojawiają się w zespole znamion art. 280 k.k.r. z 1903 r., N. Tagancew zinterpretował jako użycie „słów lub wyrażeń, które wprost obrażają pojęcia dobrych obyczai i przystojności publicznej”"11.

Już na tym etapie wykładni historycznej, prawnoporównawczej, celowościowej i językowej widać, że pojęcia obyczajności, będącego rodzajowym przedmiotem ochrony Rozdziału XVI k.w., nie można ograniczać jedynie do sfery „norm dotyczących spraw intymnych", jak uczynił to sąd w glosowanym judykacie. Nie chodziło

6 A. Mogilnicki, E.S. Rappaport, Ustawy karne tymczasowo obowiazujace w okręgach sąów apelacyjnych $w$ Warszawie, Lublinie $i$ Wilnie, t. 1: Kodeks karny z ustawami dodatkowemi, Warszawa 1928, s. 261. Podobnie: W. Makowski, Kodeks karny obowiazujący tymczasowo w Rzeczypospolitej Polskiej na ziemiach b. zaboru rosyjskiego, t. 2, Warszawa 1921, s. 338-339.

7 Akta nr 2523, 1921 rok, „Zbiór Orzeczeń Sądu Najwyższego. Orzeczenia Izby Drugiej (Karnej)" 1922, poz. 27.

8 Akta nr 1377, 1923 rok, „Zbiór Orzeczeń Sądu Najwyższego. Orzeczenia Izby Drugiej (Karnej)" 1923, poz. 144

9 W. Makowski, op. cit., s. 339.

10 N. Tagancew, Kodeks karny, Warszawa 1921, s. 266.

11 Ibidem. 
bowiem nigdy jedynie o sferę intymną i seksualną, lecz o to, czego nie przystoi czynić publicznie, co narusza dobre obyczaje zachowania publicznego. Właśnie taką wykładnię przyjęto, formułując pierwsze propozycje ujęcia późniejszego art. 31 Prawa o wykroczeniach z 1932 r. W swojej opinii do projektu wstępnego ustawy o wykroczeniach z 1929 r. sędzia Sądu Najwyższego K. Berezowski określił wyraźnie planowany zakres karalności jako obejmujący czyny bezwstydne, czyli obrażające wstydliwość, jak również te, które nie wynikają z pobudliwości płciowej i nie są skierowane na podniecenie owej pobudliwości ${ }^{12}$. Jak zauważył: „,...] co innego débauche [rozwiązłość, rozpusta], a co innego impudence [bezczelność, zuchwałość]"'13. W wersji projektu z 1931 r. konsekwentnie następuje wzbogacenie treści ówczesnego art. 26 o publiczne dopuszczenie się, oprócz czynu obrażającego wstydliwość, także nieobyczajnego wybryku, wywołującego zgorszenie publiczne. Jak wyjaśnił E.S. Rappaport w uzasadnieniu projektu, istnieje trzecia kategoria czynów „stanowiących pewien dość znaczny interes z punktu widzenia prawa karnego", oprócz czynów obrażających wstydliwość i czynów nierządnych, nastawionych na podniecenie pobudliwości płciowej (karalnych jako przestępstwo), w postaci właśnie nieobyczajnego wybryku. Wybryk nieobyczajny pozbawiony jest, jak odnotował wspomniany autor, jakiegokolwiek celu przestępnego, sam przez się jednak narusza dobre obyczaje i wywołuje publiczne zgorszenie ${ }^{14}$. Chodzi o czyn wymierzony przeciwko obyczajności powszechnej, sprowadzający się do zaniepokojenia ludzi w ich poczuciu porządku zewnętrznego ${ }^{15}$.

Należy tu wspomnieć, że wzorowano się również na ówcześnie obowiązującym $\S 360$ pkt 11 niemieckiego Kodeksu karnego, na gruncie którego ujmowano omawiany wybryk jako naruszający „ogólną obyczajność powszechną (Verkehrssitte), będącą regulatorem stosunków między ludźmi pod względem zewnętrznym i zapewniającą ich trwałość"16. Jako przykłady nieobyczajnego wybryku E.S. Rappaport podał rzucanie kamieniami na cudzy dach, chodzenie na czworakach pu-

12 Opinja artykułowana Sędziego Sądu Najwyższego Konrada Berezowskiego, [w:] Projekt wstepny Ustawy o wykroczeniach, t. 4, z. 4, s. 91.

13 Ibidem.

14 E.S. Rappaport, Uzasadnienie, [w:] Projekt wstepny Ustawy o wykroczeniach administracyjnych..., t. 5, z. 7, s. 29.

15 Ibidem. Trudno nie zauważyć, iż w sprawie Gough v. Zjednoczone Królestwo (wyrok z dnia 28 października 2014 r., skarga nr 49327/11) Europejski Trybunał Praw Człowieka określił pokazywanie się nago w miejscach publicznych, a zatem nieobyczajny wybryk z punktu widzenia art. 140 k.w., jako zachowanie, ,[które] nie tylko jest [...] sprzeczne z normami akceptowalnego zachowania w miejscach publicznych w każdym współczesnym społeczeństwie demokratycznym, lecz także może budzić poruszenie oraz obrażać moralność lub inne uczucia u niczego niespodziewających się członków społeczeństwa, zajmujących się w tym czasie swoimi zwykłymi sprawami”.

16 Por. R.A. Leżański, Kodeks karny obowiązujący na ziemiach zachodnich Rzeczypospolitej Polskiej, Poznań 1930, s. 286. 
blicznie czy przewrócenie szyldu przy cudzym sklepie ${ }^{17}$. W okresie późniejszym do tego rodzaju przykładów W. Radecki dołączył wysypanie wiadra ze śmieciami na tablicę pamiątkową, demonstracyjne picie alkoholu pod pomnikiem albo rażąco hałaśliwe zachowanie się podczas uroczystości żałobnych ${ }^{18} \mathrm{czy}_{\text {picie } \mathrm{w}}$ tym czasie i miejscu alkoholu. Z kolei D. Egierska-Miłoszewska dodała zachowania osób już nietrzeźwych, takie jak zataczanie się i przewracanie, spanie w miejscu publicznym czy niechlujny wygląd (np. zabrudzenie ubrania wymiocinami) ${ }^{19}$.

Warto nadmienić, że niedługo po wejściu w życie Prawa o wykroczeniach z 1932 r. Sąd Najwyższy zajął się wykładnią jego art. $31 \mathrm{w}$ orzeczeniu z dnia 14 września 1936 r. W sprawie został oskarżony Izrael R.: ,[...] wypuścił [on] $\mathrm{w}$ obrót handlowy pomarańcze $\mathrm{z}$ etykietami, naśladującymi orła państwowego z otokiem legionowym, na którym w miejsce inicjałów »J.P.« [Józefa Piłsudskiego] umieszczono inicjały firmy »J.F.«". Sąd Najwyższy wytknął Sądowi Okręgowemu w Gdańsku, który uwolnił Izraela R. od odpowiedzialności, że nie rozważył, czy zachowanie oskarżonego ,nie wywołało lub nie mogło wywołać w społeczeństwie polskim, a w każdym razie w znacznej jego części, wrażenia wielkiej nieprzyzwoitości i grubiańskości, a w dalszym następstwie uczucia oburzenia i moralnego potępienia w takim stopniu nawet, że poszczególne jednostki zdolne były w braku reakcji władzy państwowej nawet do samoistnej represji i samosądu”. Trudno w tym miejscu nie zauważyć, że przyjęcie wykładni Sądu Okręgowego w Opolu z glosowanego orzeczenia, ograniczającej obyczajność publiczną do sfery intymnej i płciowej, prowadziłoby do wniosku, że wszystkie podane przykłady są błędne, a wyrok Sądu Najwyższego stanowi rażące naruszenie prawa poprzez jego wadliwą wykładnię. Rażąco wadliwej wykładni dopuścił się jednak Sąd Okręgowy w Opolu, o czym stanowi niniejsza glosa.

Taka szeroka wykładnia obyczajności publicznej, której nieobyczajny wybryk się sprzeciwia, utrzymała się również po wejściu w życie art. 31 Prawa o wykroczeniach z 1932 r. J. Nisenon i M. Siewierski przyjęli za E.S. Rappaportem, że nieobyczajny wybryk ,narusza dobre obyczaje, [lecz] pod pojęcie nieobyczajnego wybryku podpadają także czyny obrażające wstydliwość. Od wybryku w tem znaczeniu odróżnić należy dopuszczenie się publicznie czynu nierządnego, mającego na celu podniecenie pobudliwości płciowej”"20. Jak wskazał J. Makarewicz: ,„[...] nieobyczajność jest pojęciem związanem z wywołaniem niekorzystnego wrażenia

17 E.S. Rappaport, op. cit., s. 11.

18 W. Radecki, Wykroczenia przeciwko obyczajności publicznej, „Służba MO” 1976, nr 3, s. 314.

19 D. Egierska-Miłoszewska, Nieobyczajny wybryk (Art. 140 k.w.w teorii i praktyce), ,Zagadnienia Wykroczeń” 1979, nr 4-5, s. 67. Autorka dokonała analizy ówczesnego orzecznictwa Kolegiów do spraw wykroczeń, dostarczając bogatego materiału poglądowego z owego czasu.

20 J. Nisenon, M. Siewierski, Kodeks karny i Prawo o wykroczeniach, [b.m.w.] [b.r.w.], s. 177; M. Siewierski, Kodeks karny i Prawo o wykroczeniach. Komentarz, Warszawa 1965, s. 439. Pogląd ten znajduje kontynuację na gruncie obowiązującego Kodeksu wykroczeń. Por. M. Kulczycki, J. Zduń- 
na otoczeniu - nie chodzi tu o czyn nierządny, oparty o popęd płciowy"21. S. Glaser i A. Mogilnicki zdefiniowali czyn ,nieobyczajny” jako niemoralny, nieprzyzwoity, obrażający obyczajność publiczną ${ }^{22}$. Z kolei Sąd Najwyższy we wspomnianym orzeczeniu z dnia 14 września 1936 r., odnosząc się wprost do pojęcia nieobyczajnego wybryku, wyjaśnił, że jest nim „,zarówno czyn prostacki, grubiański i rubaszny, jako też czyn nieprzyzwoity, sprzeciwiający się w sposób rażący dobrym obyczajom, lekceważący otoczenie i wywołujący nastrój oburzenia i potępienia ze strony osób go spostrzegających”. Jednocześnie „pojęcia tego »nieobyczajny wybryk« nie należy [...] utożsamiać z czynami kolidującymi z obyczajnością sensu stricto, naruszającymi skutkiem zmysłowości przedmiotowo poczucie publicznej moralności i wstydliwości”23. Podobnie Sąd Najwyższy podkreślił w innym judykacie: ,$[\ldots]$ nieobyczajność jest pojęta w tym przepisie w szerokim znaczeniu. Dlatego też nieobyczajnym wybrykiem będzie rażące wykroczenie przeciw powszechnie przyjętym formom publicznego zachowania się"24.

Owa szeroka wykładnia obyczajności publicznej utrzymała się też po wejściu w życie obowiązującego Kodeksu wykroczeń i jest obecnie kontynuowana ${ }^{25}$. Jak wyjaśnia W. Radecki, przez pojęcie obyczaju należy rozumieć „,powszechnie przyjętą w danym środowisku oraz tradycyjną formę zachowania się”. A dalej: ,[...] obyczaj oznacza coś zbiorowego, gromadnego, a zarazem tradycją uświęconego, co panuje w pewnej warstwie, w pewnym kraju, w pewnym narodzie. [...] Osoby znajdujące się wewnątrz grupy poddają się obyczajowi, uznają go"26.

Obyczajność publiczna obejmuje formy zachowania w obecności innych osób bądź w miejscu, do którego mają dostęp inne osoby. Obyczajność publiczną należy zatem interpretować jako sposób zachowania się przyjęty w pewnej grupie

czyk, Kodeks wykroczeń. Popularny komentarz, Warszawa 1982, s. 170; idem, O nowym kodeksie wykroczeń, Warszawa 1972, s. 190.

21 J. Makarewicz, Kodeks karny z komentarzem, Lwów 1938, s. 683.

22 S. Glaser, A. Mogilnicki, Prawo o wykroczeniach. Komentarz, Kraków 1934, s. 48.

23 3K 1035/36, „Zbiór Orzeczeń Izby Karnej Sądu Najwyższego” 1937, poz. 48. Pogląd ten znajduje kontynuację na gruncie obowiązującego Kodeksu wykroczeń. Por. M. Kulczycki, J. Zduńczyk, Kodeks wykroczeń..., s. 170; idem, O nowym kodeksie..., s. 190-191; J. Bafia, [w:] J. Bafia, D. Egierska, I. Śmietanka, Kodeks wykroczeń. Komentarz, Warszawa 1980, s. 328; B. Kurzępa, Kodeks wykroczeń. Komentarz, Warszawa 2008, s. 475-476.

24 Za: K. Boryczko, F. Kuc, Kodeks karny, Prawo o wykroczeniach i Przepisy wprowadzajace z orzecznictwem, Kraków [b.r.w.], s. 189.

25 Przytoczone powyżej w przypisach poglądy doktryny zostały wyrażone na gruncie obowiązującego Kodeksu wykroczeń, powielając uprzednio sformułowane.

26 W. Radecki, Wykroczenia przeciwko obyczajności..., s. 310; idem, Wybrane zagadnienia części szczególnej prawa wykroczeń, [w:] M. Bojarski, A. Gubiński, W. Radecki, S. Stachowiak, Wybrane zagadnienia materialnego i procesowego prawa o wykroczeniach, Warszawa 1986 (wkładka do „Zagadnień Wykroczeń” 1986, nr 4-5), s. 85. Por. podobnie: D. Egierska-Miłoszewska, op. cit., s. 67; W. Kotowski, Kodeks wykroczeń. Komentarz, Warszawa 2009, s. 692; J. Piórkowska-Flieger, [w:] Kodeks wykroczeń. Komentarz, red. T. Bojarski, Warszawa 2015, s. 572. 
społecznej, który jest wymagany przez tę grupę i którego naruszenie wywołuje negatywną reakcję tej grupy bądź jest zdolne do wywołania takiej reakcji ${ }^{27}$. Dla J. Bafii „nieobyczajnym wybrykiem jest czyn, który narusza zasady współżycia społecznego w zakresie dobrych obyczajów i zdolny jest wywołać zgorszenie u przeciętnego obywatela", to czyn ,przeciwko wszelkim powszechnie przyjmowanym obyczajom życia publicznego"28. Z kolei D. Egierska-Miłoszewska owo zgorszenie traktuje jako negatywną, potępiającą reakcję otoczenia na nieobyczajne zachowanie sprawcy ${ }^{29}$. T. Bojarski zachowanie naruszające obyczajność publiczną identyfikuje z zachowaniami wykraczającymi przeciwko normom kulturowym, przyjętym zwyczajom i obyczajom zachowań ludzi w miejscu publicznym bądź zachowań publicznych oraz zasadom współżycia społecznego. Jak podaje, ich istotę można wyrazić określeniem „,prymitywizm” lub „wulgaryzm” obyczajowy, przez który sprawca wykazuje brak taktu w warunkach życia zbiorowego. Jest on sprzeczny z normami kultury, odróżniającymi działalność człowieka od działania innych istot ${ }^{30}$. Według J. Piórkowskiej-Flieger obyczajność publiczna to zespół norm obyczajowych dotyczących ogółu społeczeństwa. Mają one obejmować różne sfery życia człowieka, także sferę intymną, w tym życie seksualne i procesy fizjologiczne, jak również dopuszczalne zachowania względem innych ludzi. Nieobyczajnym wybrykiem jest więc ,zachowanie lekceważące zasady współżycia społecznego i w konsekwencji mogące wywołać negatywną ocenę przeciętnego człowieka"31. Jak wyjaśnia M. Mozgawa, nieobyczajne zachowanie poprzez naruszenie norm obyczajowych wywołuje uczucie wstydu, zażenowania, zakłopotania ${ }^{32}$. W wyroku z dnia 2 grudnia 1992 r. Sąd Najwyższy wskazał z kolei na „przyjęte zwyczajowo normy współżycia ludzi”, „powszechnie akceptowane normy zachowania się", których naruszenie „wywołuje powszechne negatywne oceny społeczne i odczucia odrazy, gniewu, oburzenia" 33 .

Nieprzyzwoitość, która należy do zespołu znamion czynu z art. 141 k.w., jest interpretowana przez M. Mozgawę zgodnie z wykładnią językową jako zachowanie niezgodne z panującymi normami obyczajowymi, zasadami, etykietą, jako zachowanie nieskromne, bezwstydne, niewłaściwe ${ }^{34}$. Nieprzyzwoitość jest identy-

27 W. Radecki, Wykroczenia przeciwko obyczajności..., s. 311-312; M. Mozgawa, [w:] Kodeks wykroczeń. Komentarz, Warszawa 2009, s. 497.

28 J. Bafia, op. cit., s. 328-29. Por. podobnie: W. Kotowski, op. cit., s. 691.

29 D. Egierska-Miłoszewska, op. cit., s. 66. Por. podobnie: B. Kurzępa, op. cit., s. 475; W. Kotowski, op. cit., s. 691.

30 T. Bojarski, Polskie prawo wykroczeń. Zarys wykładu, Warszawa 2012, s. 195.

31 J. Piórkowska-Flieger, op. cit., s. 572-573.

32 M. Mozgawa, op. cit., s. 497.

33 III KRN 189/92, LEX nr 162227. Podobnie: W.J. Jankowski, [w:] M. Błaszczyk, W.J. Jankowski, M. Zbrojewska, Prawo i postępowanie w sprawach o wykroczenia, Warszawa 2013, s. 172.

34 M. Mozgawa, op. cit., s. 499. Por. podobnie: B. Kurzępa, op. cit., s. 476. 
fikowana ze wzbudzaniem powszechnego zgorszenia oraz ze wzbudzaniem zgorszenia u przeciętnego człowieka ${ }^{35}$. Według J. Bafii chodzi o bezwstydność, lecz także o możliwość wzbudzenia oburzenia społecznego lub wyrażenie lekceważenia innych ludzi ${ }^{36}$. Taka wykładnia spotkała się z aprobatą W. Radeckiego, który wskazuje, że J. Bafia słusznie nie ograniczył pojęcia nieprzyzwoitości do kwestii związanych z życiem płciowym ${ }^{37}$. Również W. Kotowski, oprócz zachowania bezwstydnego, zwrócił uwagę na zachowanie niezgodne z panującymi normami obyczajowymi, niewłaściwe ${ }^{38}$. Jak przytoczono wyżej, w kontekście nieprzyzwoitości T. Bojarski odwołuje się do naruszenia norm kulturowych i przyjętych obyczajów w zakresie zachowań w miejscach publicznych ${ }^{39}$.

Podsumowując, obyczajność publiczna chroniona w Rozdziale XVI k.w. obejmuje powszechnie przyjęty i wymagany sposób zachowania w obecności innych osób bądź w miejscu, do którego mają dostęp inne osoby, którego naruszenie wywołuje negatywną reakcję innych osób w postaci zakłopotania, zażenowania, zgorszenia, gniewu, oburzenia, sprzeciwu, odrazy, potępienia bądź jest zdolne do wywołania takiej reakcji. Nieobyczajne zachowanie to takie, które sprzeciwia się w powyższym kontekście normom kulturowym, zasadom współżycia społecznego, przyjętym zwyczajom i obyczajom zachowań jednostek w miejscu publicznym bądź zachowań publicznych. Pojęcie obyczajności, obyczajności publicznej i nieobyczajnego wybryku nigdy nie ograniczało się do sfery intymnej czy płciowej jednostki. Podobnie w stosunku do pojęcia nieprzyzwoitości brak jest podstaw do zawężającej wykładni. Jeśli sąd w glosowanym judykacie wskazuje na wykładnię językową tego pojęcia, przywołując jako jego synonim pojęcie nieobyczajności, to dostarcza tym samym argumentu dla obalenia swojej wykładni. Skoro obyczajność (nieobyczajność) nigdy nie ograniczała się do sfery płciowej i intymnej, a jej synonimem jest przyzwoitość (nieprzyzwoitość), to również to pojęcie domaga się szerokiej wykładni. Co więcej, nie mamy do czynienia z wykładnią rozszerzającą, czego obawia się sąd, tylko z wykładnią zgodną z jej zasadami oraz z zasadami logicznego rozumowania.

W swej błędnej wykładni sąd następnie odwołał się do uchwały Sądu Najwyższego z dnia 13 kwietnia 1977 r. dotyczącej przedmiotu ochrony obecnego Rozdziału XXV k.k., głoszącej, iż obyczajność to podstawowe moralne zasady współżycia społecznego w zakresie przeżyć, kontaktów i związków seksualnych ${ }^{40}$. Jak stwierdził, tak samo należy interpretować obyczajność na gruncie Rozdziału

\footnotetext{
35 M. Kulczycki, J. Zduńczyk, Kodeks wykroczeń..., s. 171; idem, O nowym kodeksie..., s. 191.

36 J. Bafia, op. cit., s. 329. Por. podobnie: B. Kurzępa, op. cit., s. 476.

37 W. Radecki, Wykroczenia przeciwko obyczajności..., s. 321.

38 W. Kotowski, op. cit., s. 692.

39 T. Bojarski, op. cit., s. 195.

40 Uchwała SN z dnia 13 kwietnia 1977 r., VII KZP 30/76, LEX nr 19263.
} 
XVI k.w. Ponownie, gdyby sąd sięgnął do piśmiennictwa, wówczas by zauważył, że w doktrynie powszechnie przyjmuje się $e^{41}$, iż przytoczona wykładnia Sądu Najwyższego jest nieprzenaszalna na grunt Kodeksu wykroczeń. Umyka bowiem uwadze sądu, że obyczajność w Kodeksie karnym musi być ograniczona do sfery intymnej i seksualnej, ponieważ towarzyszy jej jako przedmiot ochrony wolność seksualna. Byłoby nieracjonalne (tymczasem sąd odwołuje się do racjonalności ustawodawcy) objęcie przez ustawodawcę całego zakresu obyczajności ochroną Rozdziału XXV k.k., skoro przeważająca część typów rodzajowych odnosi się do wolności seksualnej jednostki, a więc do sfery intymnej i płciowej. Natomiast na gruncie Kodeksu wykroczeń nie ma podstaw do twierdzenia, że ustawodawca ogranicza w jakikolwiek sposób zakres przedmiotu ochrony, jakim jest obyczajność, ponieważ nie tylko podnosi ją do rangi samodzielnego dobra prawnego ${ }^{42}$, lecz dodatkowo jeszcze wskazuje, że chodzi o sferę relacji między jednostkami w ramach współżycia społecznego, obyczajów i zwyczajów, oraz dodaje do niej przymiotnik „publiczna”. Jako całkowicie niezrozumiały należy uznać wywód sądu, w którym stwierdził: ,[...] przymiotnik »publiczna« wzmacnia to [ograniczone do sfery intymnej] znaczenie, świadcząc jednoznacznie o tym, że dobrem chronionym jest utrzymanie intymnej sfery życia w miejscach publicznych w odpowiednich, powszechnie przyjętych ryzach". Jak zauważa J. Piórkowska-Flieger, tytuł Rozdziału XVI k.w. wskazuje na obyczajność publiczną, a nie ograniczoną do obyczajności w sferze płciowej czy intymnej ${ }^{43}$. Z kolei W. Radecki podkreśla, że w ramach Rozdziału XVI k.w. tylko art. 142 odsyła do obyczajności w dziedzinie płciowej. Co istotne, bez tego rodzaju wyraźnej wskazówki w treści pozostałych dwóch artykułów nie można ograniczać obyczajności jako rodzajowego i indywidualnego przedmiotu ochrony art. 140 i 141 k.w. jedynie do sfery płciowej i intymnej ${ }^{44}$.

W kontekście wykładni systemowej należy też zauważyć, iż w doktrynie przyjmuje się, że czyny z art. 140-142 k.w. są zbliżone do wykroczeń przeciwko porządkowi i spokojowi publicznemu i mogły być włączone do Rozdziału VIII k.w. ${ }^{45}$ Art. 280 k.k.r. z 1903 r. znajdował się w części pt. „O pogwałceniu przepisów o nadzorze nad moralnością publiczną", przy czym w rozdziale tym znajdowały się również przestępstwa, które obecnie należałoby identyfikować z pogwałceniem porządku publicznego, jak choćby „otwarcie zabawy ludowej bez pozwolenia” (art. 288),

${ }_{41}$ W. Radecki, Wybrane zagadnienia ..., s. 85; M. Mozgawa, op. cit., s. 497; J. Piórkowska-Flieger, op. cit., s. 573.

42 D. Egierska, Nowe wykroczenia, „Zagadnienia Karno-Administracyjne” 1969, nr 5, s. 21;

A. Gubiński, Prawo..., s. 336; idem, [w:] T. Grzegorczyk, A. Gubiński, op. cit., s. 253.

43 Por. J. Piórkowska-Flieger, op. cit., s. 573.

44 W. Radecki, Wykroczenia przeciwko obyczajności..., s. 310 (tu również szersze uzasadnienie jego trafnego stanowiska).

45 A. Gubiński, Prawo..., s. 336; idem, [w:] T. Grzegorczyk, A. Gubiński, op. cit., s. 253. Por. podobnie: J. Piórkowska-Flieger, op. cit., s. 571. 
„picie publicznie napojów wyskokowych” (art. 286) czy „urządzanie gry w karty, w kości itp., zabronionej przez ustawę lub rozporządzenie" (art. 289). Jednocześnie osobna Część XII stanowiła „O pogwałceniu przepisów ochraniających spokój publiczny", obejmując choćby pierwowzór obecnego art. $51 \mathrm{k} . \mathrm{w}$. W projekcie wstępnym ustawy o wykroczeniach z 1929 r. odpowiedni art. 32 został umieszczony w Rozdziale V „Wykroczenia przeciwko moralności”. W kolejnej wersji z lat 1929-1930 wówczas już art. 34 zamieszczono w Rozdziale V, ale zatytułowanym „Wykroczenia przeciwko obyczajności publicznej”. W wersji z 1931 r. przewidziano jedną „Część szczególną”, bez dodatkowego wewnętrznego podziału na kolejne rozdziały. Wreszcie we wprowadzonym w życie Prawie o wykroczeniach z 1932 r. art. 31 został umieszczony w Rozdziale II ,Wykroczenia przeciwko porządkowi publicznemu". Umiejscowienie to utrzymało się w projekcie Prawa o wykroczeniach z 1961 r., ostatecznie jednak wyodrębniono osobny rozdział w obowiązującym kształcie i tytule (projekty z lat 1967 i 1970). Mimo to niezmiennie pojawiały się postulaty połączenia art. $140 \mathrm{i} 141 \mathrm{k} . \mathrm{w}$. w jeden artykuł z dwoma paragrafami oraz ich dodania wraz z art. 142 k.w. do Rozdziału VIII z następującym uzasadnieniem: ,$[\ldots]$ dalsze wyszczególnianie tego dodatkowego przedmiotu ochrony [...] nie ma, jak się wydaje, głębszego uzasadnienia ani w teorii, ani w praktyce" ${ }^{\text {"46 }}$. I rzeczywiście, w projekcie Kodeksu wykroczeń z 1991 r. zaproponowano zniesienie Rozdziału XVI i włączenie art. 140 k.w. do Rozdziału VIII „Wykroczenia przeciwko porządkowi i spokojowi publicznemu". Jak widać, obyczajność publiczną zawsze łączono z jeszcze ogólniejszym przedmiotem ochrony, jakim jest porządek publiczny. Dla wykładni zawężającej zastosowanej przez sąd również z tego punktu widzenia nie ma miejsca.

Osobne rozważania, których wniosku jednak nie można podzielić, sąd poświęcił zagadnieniu korzystania przez prolajferów z wolności wypowiedzi. W pełni można zaakceptować stwierdzenie:

[...] kwestia aborcji jest ważkim i fundamentalnym problemem społecznym. Tematyka ta budzi żywe zainteresowanie społeczne, jako związana z ochroną życia ludzkiego. Prawo do wyrażania poglądów nie zawsze ogranicza się do kwestii miłych, akceptowanych przez wszystkich lub większość. [...] Dotyczy to także poglądów, które mogą mieć charakter kontrowersyjny czy wręcz „szokujący” ze względu na sposób ich wyrażania [...].

W związku z tym sąd skonstatował: „[...] jeśli ustawodawca chciałby, ze względu na sposób prezentacji tych poglądów, ograniczyć to prawo, to winien to jednoznacznie wyrazić w przepisach. Ograniczenia konstytucyjnego uprawnienia

46 Z. Kocel-Krekora, Rozdziat VIII Kodeksu wykroczeń ,,Wykroczenia przeciwko porzadkowi $i$ spokojowi publicznemu” w świetle reformy prawa o wykroczeniach, „Zagadnienia Wykroczeń” 1989, nr 3, s. 63. 
do swobodnego wyrażania poglądów nie można domniemywać, w tym poprzez rozszerzającą wykładnię nieostrych pojęć".

Zagadką pozostaje, co dokładnie miał na myśli sąd, domagając się ,jednoznacznego wyrażenia w przepisach". Czy chciałby znaleźć w Kodeksie wykroczeń przepis o brzmieniu: Kto publicznie prezentuje zdjęcia martwych ludzkich płodów, podlega karze [...]? Przepis taki jest zbędny, ponieważ zastosowanie do takich zachowań znajdują art. $51 \S 1$, art. 140 albo art. 141 k.w., chroniące obyczajność publiczną także przed publicznym prezentowaniem zdjęć czy obrazów, które mogą wywołać negatywną reakcję innych osób w postaci zakłopotania, zażenowania, zgorszenia, gniewu, oburzenia, sprzeciwu, odrazy, potępienia. Przepisy te chronią też przed pojawianiem się $\mathrm{w}$ przestrzeni publicznej prezentacji sprzecznych $\mathrm{z}$ normami kulturowymi czy zasadami współżycia społecznego. I nie jest to kwestia wykładni rozszerzającej wcale nie tak nieostrych pojęć, jak to się jawi sądowi, lecz wykładni prawidłowej, której sąd nie dokonał, co wykazano powyżej.

Nie można nie wspomnieć, że oprócz art. 51, 140 czy 141 k.w. w systemie prawa penalnego funkcjonują i inne typy rodzajowe, które ograniczają wolność wypowiedzi nie ze względu na jej treść, lecz właśnie z uwagi na formę, ich znamiona zaś nie są bardziej klarowne niż „nieprzyzwoitość” według wykładni zastosowanej przez sąd. Dość wspomnieć o wszystkich typach bazujących na znamieniu „zniewagi”: art. 133 k.k., art. 135 § 2 k.k., art. 137 k.k., art. 196 k.k., art. 226 k.k., art. 257 k.k. czy art. 3 ustawy z dnia 10 czerwca 2014 r. o ochronie Znaku Polski Walczącej ${ }^{47}$. Żaden $\mathrm{z}$ tych przepisów nie zawiera $\mathrm{w}$ zespole znamion jednoznacznego opisu zakazanego „sposobu prezentacji” poglądów, poprzestając na znamieniu czynnościowym „znieważania”. Taki właśnie sposób formułowania norm prawnokarnych jest przyjmowany w polskiej kulturze prawnej - syntetyczny, a nie kazuistyczny. Chyba że sąd stoi na stanowisku, że żaden z tych przepisów nie może być nigdy przez sąd karny stosowany, ponieważ zostałby on zmuszony do „rozszerzającej wykładni nieostrych pojęć", a każde zachowanie znieważające ,jest kwestią wysoce ocenną i pozostaje w tym przypadku poza reglamentacją Kodeksu wykroczeń” czy Kodeksu karnego.

Co więcej, nie można zgodzić się z sądem, gdy argumentuje: ,[...] w przestrzeni publicznej powszechnie obecne są drastyczne środki wyrazu (np. reklamy antynikotynowe na opakowaniach papierosów)". Być może miasto Opole wykazuje w tym zakresie jakąś odrębność na tle reszty Rzeczypospolitej Polskiej. Tymczasem w naszym kraju na ulicach, placach, parkingach, przed cmentarzami, szpitalami czy na wielkoformatowych billboardach nie prezentuje się ,powszechnie" (bo nie prezentuje się w ogóle) autentycznych barwnych zdjęć zakrwawionych, porozrywanych ludzkich zwłok. Normy kulturowe, zasady współżycia społecznego, przyjęte zwyczaje i obyczaje nakazują otaczanie ludzkich zwłok szacunkiem, co wynika wprost z nauki

${ }^{47}$ Dz.U. 2014, poz. 1062. 
Kościoła katolickiego, przyjmowanej przez przytłaczającą większość społeczeństwa polskiego ${ }^{48}$, oraz z uniwersalnych zasad szacunku dla człowieka jako inkorporującego swą przyrodzoną i niezbywalną godność. Jak głosi Katechizm Kościoła Katolickiego: „Ciała zmarłych powinny być traktowane z szacunkiem i miłością wypływającą z wiary i nadziei zmartwychwstania" ${ }^{49}$. Trudno przyjąć, by wystawianie na widok publiczny z jakąkolwiek intencją barwnych zdjęć zakrwawionych ludzkich zwłok, nieraz rozczłonkowanych, mogło realizować nakaz traktowania z szacunkiem osoby, która została na takim zdjęciu utrwalona. Stanowi to instrumentalne potraktowanie tej osoby, sprzeczne z nakazem poszanowania jej godności. Oczywiste jest zatem, że tego rodzaju prezentacji nie ma w miejscach publicznych.

Odnośnie do zdjęć ostrzegających przed szkodliwością palenia umieszczanych na opakowaniach papierosów należy zauważyć, że są one niewielkie i przez to mało czytelne, znajdują się wyłącznie w placówkach handlowych i są skierowane do osób, które chcą sięgnąć po papierosy, a nie do każdej przypadkowej osoby. Ich dostrzeżenie w tego rodzaju placówce oraz odbiór treści ze zrozumieniem wymaga wysiłku. Należy też odnotować, że ostrzeżenie „Palenie zmniejsza płodność” posługuje się, co prawda, obrazem płodu ludzkiego, lecz obraz ten został usypany z popiołu spalanego papierosa - nie posłużono się zdjęciem rzeczywistego płodu.

\section{BIBLIOGRAFIA}

Akta nr 2523, 1921 rok, „Zbiór Orzeczeń Sądu Najwyższego. Orzeczenia Izby Drugiej (Karnej)” 1922, poz. 27.

Akta nr 1377, 1923 rok, „Zbiór Orzeczeń Sądu Najwyższego. Orzeczenia Izby Drugiej (Karnej)” 1923, poz. 144.

Bafia J., [w:] J. Bafia, D. Egierska, I. Śmietanka, Kodeks wykroczeń. Komentarz, Warszawa 1980.

Bojarski T., Polskie prawo wykroczeń. Zarys wykładu, Warszawa 2012.

Boryczko K., Kuc F., Kodeks karny, Prawo o wykroczeniach i Przepisy wprowadzajace z orzecznictwem, Kraków [b.r.w.].

Dekret z dnia 9 kwietnia 1946 r. o zmianie prawa o wykroczeniach (Dz.U. 1946, nr 15, poz. 108). Egierska D., Nowe wykroczenia, „Zagadnienia Karno-Administracyjne” 1969, nr 5.

Egierska-Miłoszewska D., Nieobyczajny wybryk (Art. 140 k.w.w teorii i praktyce), „Zagadnienia Wykroczeń" 1979, nr 4-5.

Glaser S., Mogilnicki A., Prawo o wykroczeniach. Komentarz, Kraków 1934.

Gubiński A., [w:] T. Grzegorczyk, A. Gubiński, Prawo wykroczeń, Warszawa 1996.

Gubiński A., Prawo wykroczeń, Warszawa 1985.

Jankowski W.J., [w:] M. Błaszczyk, W.J. Jankowski, M. Zbrojewska, Prawo i postępowanie w sprawach o wykroczenia, Warszawa 2013.

Katechizm Kościoła Katolickiego, Poznań 1994.

${ }^{48}$ W tym działaczy pro-life, którzy przecież czerpią uzasadnienie dla swego sprzeciwu wobec aborcji wprost z Pisma Świętego.

49 Katechizm Kościoła Katolickiego, Poznań 1994, pkt 2300. 
Kocel-Krekora Z., Rozdział VIII Kodeksu wykroczeń ,, Wykroczenia przeciwko porzadkowi i spokojowi publicznemu” w świetle reformy prawa o wykroczeniach, „Zagadnienia Wykroczeń” 1989, nr 3.

Kotowski W., Kodeks wykroczeń. Komentarz, Warszawa 2009.

Kulczycki M., Zduńczyk J., Kodeks wykroczeń. Popularny komentarz, Warszawa 1982.

Kulczycki M., Zduńczyk J., O nowym kodeksie wykroczeń, Warszawa 1972.

Kulesza J., Glosa do wyroku Sądu Okręgowego we Wroctawiu z 25.07.2019 r., IV Ka 677/19, „Państwo i Prawo" (złożona do druku).

Kulesza J., Publiczne prezentowanie zdjęć martwych płodów jako nieobyczajny wybryk (art. 140 Kodeksu wykroczeń), „Studia Prawnicze” 2019, nr 2.

Kulesza J., Publiczne prezentowanie zdjęć martwych płodów jako wybryk zakłócenia spokoju i porządku publicznego bądź wywołania zgorszenia (art. 51 \& 1 Kodeksu wykroczeń), „Ruch Prawniczy, Ekonomiczny i Socjologiczny" (złożony do druku).

Kulesza J., Publiczne prezentowanie zdjęć martwych płodów przez działaczy pro-life w orzecznictwie sąów powszechnych. Analiza krytyczna, [w:] Pro dignitate legis et maiestate iustitiae. Księga jubileuszowa z okazji 70. rocznicy urodzin Profesora Witolda Kuleszy, red. A. Liszewska, J. Kulesza, Łódź 2020.

Kulesza J., Wybryk nieobyczajny publicznego prezentowania zdjęć martwych płodów a ochrona wolności wypowiedzi w świetle orzecznictwa ETPC, „Studia Prawno-Ekonomiczne” (przyjęty do druku).

Kurzępa B., Kodeks wykroczeń. Komentarz, Warszawa 2008.

Leżański R.A., Kodeks karny obowiązujący na ziemiach zachodnich Rzeczypospolitej Polskiej, Poznań 1930.

Makarewicz J., Kodeks karny z komentarzem, Lwów 1938.

Makowski W., Kodeks karny obowiazujący tymczasowo w Rzeczypospolitej Polskiej na ziemiach b. zaboru rosyjskiego, t. 2, Warszawa 1921.

Mogilnicki A., Rappaport E.S., Ustawy karne tymczasowo obowiązujące w okręgach sąów apelacyjnych w Warszawie, Lublinie i Wilnie, t. 1: Kodeks karny z ustawami dodatkowemi, Warszawa 1928.

Mozgawa M., [w:] Kodeks wykroczeń. Komentarz, Warszawa 2009.

Nisenon J., Siewierski M., Kodeks karny i Prawo o wykroczeniach, [b.m.w.] [b.r.w.].

Opinja artykułowana Sędziego Sądu Najwyższego Konrada Berezowskiego, [w:] Projekt wstępny Ustawy o wykroczeniach, oprac. E.S. Rappaport, t. 4, z. 4, Komisja Kodyfikacyjna Rzeczypospolitej Polskiej. Sekcja Prawa Karnego, Warszawa 1929.

Orzeczenie SN z dnia 14 września 1936 r., 3K 1035/36, „Zbiór Orzeczeń Izby Karnej Sądu Najwyższego" 1937, poz. 48.

Piórkowska-Flieger J., [w:] Kodeks wykroczeń. Komentarz, red. T. Bojarski, Warszawa 2015.

Projekt wstepny Ustawy o wykroczeniach administracyjnych wraz z sumarycznem uzasadnieniem, oprac. E.S. Rappaport, R. Lemkin, t. 5, z. 7, Komisja Kodyfikacyjna Rzeczypospolitej Polskiej. Sekcja Prawa Karnego, Warszawa 1931.

Projekt wstępny Ustawy o wykroczeniach, oprac. E.S. Rappaport, t. 4, z. 4, Komisja Kodyfikacyjna Rzeczypospolitej Polskiej. Sekcja Prawa Karnego, Warszawa 1929.

Radecki W., Wybrane zagadnienia części szczególnej prawa wykroczeń, [w:] M. Bojarski, A. Gubiński, W. Radecki, S. Stachowiak, Wybrane zagadnienia materialnego i procesowego prawa o wykroczeniach, Warszawa 1986 (wkładka do „Zagadnień Wykroczeń” 1986, nr 4-5).

Radecki W., Wykroczenia przeciwko obyczajności publicznej, „Służba MO” 1976, nr 3.

Rappaport E.S., Uzasadnienie, [w:] Projekt wstęny Ustawy o wykroczeniach administracyjnych wraz z sumarycznem uzasadnieniem, Komisja Kodyfikacyjna Rzeczypospolitej Polskiej. Sekcja Prawa Karnego, oprac. E.S. Rappaport, R. Lemkin, t. 5, z. 7, Warszawa 1931.

Siewierski M., Kodeks karny i Prawo o wykroczeniach. Komentarz, Warszawa 1965. 
Tagancew N., Kodeks karny, Warszawa 1921.

Uchwała SN z dnia 13 kwietnia 1977 r., VII KZP 30/76, LEX nr 19263.

Ustawa z dnia 10 czerwca 2014 r. o ochronie Znaku Polski Walczącej (Dz.U. 2014, poz. 1062).

Wyrok SN z dnia 2 grudnia 1992 r., III KRN 189/92, LEX nr 162227.

\section{SUMMARY}

In the commented judgement, the court discharged the responsibility of individuals who presented banners with photographs of human remains after abortions in front of the obstetrics hospital in Opole. They had been charged with public display of obscenity (Article 141 of the Petty Offences Code). Not only the discharge was wrong, although it is possible to apply Article 140 of the Petty Offences Code instead of Article 141, as the formerly prescribed responsibility for public indecency. The court applied also a completely erroneous interpretation of the presentation of public indecency, as limited to the intimate and gender sphere. Historical, comparative, linguistic, teleological and systematic interpretations indicate that public decency includes a commonly accepted and required public behavior, the violation of which causes or may cause negative reactions of others in the form of embarrassment, scandal, anger, opposition, condemnation. Such punishable public indecency is any that opposes cultural norms, rules of social coexistence, accepted customs of public behavior of individuals.

Keywords: pro-life activity; freedom of speech; public morality; public order; criminal responsibility 